\title{
THE CALIFORNIA PENALTY TRIAL
}

The people of the state of California, through the legislative branch of the government, have declined to eliminate the death penalty. Yet, it would appear that the will of the people, as expressed through the legislative branch of the government, has been overruled by the judiciary.-People v. Hines (Cal. 1964) (McComb, J., dissenting).

Justice McComb's remarks were directed to the California Supreme Court's treatment of appeals from death sentences. The extraordinary number of death penalties reversed by the court over the last few years has supplied ammumition to both sides in the contmuing controversy over the death penalty in California. Fundamental questions have been raised of reconciling effective law enforcement with a fair and rational sentencing process, and both the court and its critics have been concerned with the proper role of the judiciary in the admiunstration of the death penalty.

The current trend in reversals can be traced to the enactment in 1957 of Section 190.1 of the Penal Code. ${ }^{1}$ That section provides for the so-called "penalty trial," a procedure by which a separate trial solely on the issue of punishment follows a conviction for an offense purnshable in the alternative by death or life imprisonment. ${ }^{2}$ In three recent opinions authored by Justice Tobriner ${ }^{3}$ the court has painstakingly sought to clarify the scope and purpose of the penalty trial. Characterizing the statutory sentencing procedure as a "legal vacuum," ${ }^{4}$ without effective standards for the admissibility of evidence or for the jury's resolution of the penalty issue, the court has refocused public and legislative attention on the death penalty in California. This Comment will examine the development of the California penalty trial, with particular emphasis on the problems involved when the jury is the trier of fact on the penalty issue. Part I deals with the per-

\footnotetext{
1 CAI. PEN. Code $\$ 190.1$ provides:
}

"The guilt or innocence of every person charged with an offense for which the penalty is in the alternative death or imprisonment for life shall first be determined, without a finding as to penalty. If such person has been found guilty of an offense punishable by life imprisoninent or death ... there shall thereupon be further proceedings on the issue of penalty. Evidence may be presented at the further proceedings ... of the circumstances surrounding the commission of the crime, of the defendant's background and history, and of any facts in aggravation or mitigation of the penalty. The determination of the penalty ... shall be in the discretion of the court or jury trying the issue of fact on the evidence presented ....

If the defendant was convicted by the court sitting without a jury, the trier of fact shall be the court. If the defendant was convicted by a plea of guilty, the trier of fact shall be a jury unless a jury is waived. If the defendant was convicted by a jury, the trier of fact shall be the same jury unless, for good cause shown the court discharges that jury in which case a new jury shall ... determine the issue of penalty."

The provisions of $\$ 190.1$ are mandatory, so that the issue of penalty must be tried separately from the issue of guilt. People v. Shipp, 59 Cal.2d 845, 382 P.2d 577, 31 Cal. Rptr. 457 (1963).

2 CAL. PEN. CODE $\$ \S 189,190$ (first degree murder), 209 (kidnapping with bodily harm), 219 (trainwrecking in cases where no person suffers bodily harm), 4500 (assault by hifer; victim not dying within a year and a day). The death penalty is the sole penalty prescribed for the following offenses: CAI. PEN. CODE $\$ \$ 37$ (treason), 128 (perjury resulting in conviction and execution of innocent person), 219 (traimwrecking, where any person suffers bodily harm), 4500 (assault by lifer; victim dying within a year and a day).

3 People v. Hines, ..... A.C. ...., 390 P.2d 398, 37 Cal. Rptr. 622 (1964) ; People v. Terry, ...... A.C. ......, 390 P.2d 381, 37 Cal. Rptr. 605 (1964) ; People v. Morse, 60 A.C. 613, 388 P.2d 33, 36 Cal. Rptr. 201 (1964).

4 People v. Terry, 390 P.2d at 392, 37 Cal. Rptr. at 616. 
missible scope of inquiry; Part II considers some problems of jury discretion in sentencing in capital cases. ${ }^{5}$

\section{THE SCOPE OF INQUIRY}

Of the states which use the jury to determine punishment in capital cases, California was the first to separate the determination of punishment from the determination of guilt. Pennsylvania established a separate hearing for fixing punishment in capital cases in $1959,{ }^{6}$ and New York added a similar provision in 1963.7 The statutory scheme in California is not complicated. At the first phase of the trial, the sole issue is guilt. If the defendant is found guilty of an offense for which the death penalty may be imposed, and if sanity is not in issue, further proceedings are held on the issue of punishment. At this phase of the trial, evidence is admissible "of the circunistances surrounding the crime, of defendant's background and history, and of any facts in aggravation or mitigation of the penalty." Selection of the punishment is then in the discretion of the court or jury trying the issue of penalty. ${ }^{10}$

The split trial cures a major evil in traditional sentencing procedure in capital cases. In non-capital cases, the function of the jury in nearly all American jurisdictions is hmited to determining the guilt or innocence of the accused. ${ }^{11}$ Fixing the penalty is the function of the sentencing judge or an expert body; ${ }^{12}$ by various methods a wide range of information pertinent to the imposition of punishment is received. ${ }^{13}$ In capital cases, however, the jury has been given an added task. Nearly all jurisdictions retaining the death penalty now provide an alternative punishment, life imprisonment, for first degree murder, and leave the selection of the penalty to the trier of fact. ${ }^{14}$

5 This Comment is not directly concerned with the propriety of the death penalty, nor does it consider the problems raised by the trifurcation of a capital case in California. See note 8 infra.

OPA. STAT. ANN. tit. 18, §4701: "[T] evidence not previously received in the trial as may be relevant ...." See Commonwealth v. McCoy, 405 Pa. 23, 172 A.2d 795 (1961).

7 N.Y. PENAL LAW § 1045-a.

8 When insanity is in issue, a California capital case may be trifurcated. As $\S 190.1$ was originally enacted, the order of trials was guilt, penalty and then insanity. Cal. Stat. ch. 1968, $\$ 2$ (1957). This illogical sequeance was altered by amendment so that the order of trials is now guilt, insanity and then penalty. Cal. Stat. ch. 738, \&1 (1959). The proceeding to determine sanity is governed by CAL. PEN. CODE $\S \S 1026,1027$. See generally, Louisell \& Hazard, Insanity as a Defense: The Bifurcated Trial, 49 CALrF. L. Rev. 805 (1961).

9 Car. PEn. Code $\$ 190.1$.

10 Ibid.

11 For a recent collection of statutes see Handler, Background Evidence in Murder Cases, 51 J. Crorr. L., C. \& P.S. 317 (1961).

12 In California non-capital felony cases, the trial court sentences the defendant to the minimun term prescribed by statute or grants probation pursuant to CAL. PEN. CODE $\$ 1203$. Since 1953, probation has been granted to over $40 \%$ of those convicted of felonies in Cahfornia. See Comment, 50 CAIFF. L. Rev. 651 (1962). Where probation is not granted, the non-capital felony offender is committed to the state prison for an indeterminate tern, the Adult Authority having the sole power to fix the term and duration of incarceration. Car. PEN. CODE $\$ \S 1168,3020$.

13 See CAL. PEN. Code $\$ \S 1203 c$, 1204. See also State v. White, 27 N.J. 158, 183, 142 A.2d 65, 79 (1958) (concurring opinion). See generally Comment. 50 CALF. L. REv. 651 (1962).

14 See Handler, suctra note 11 . at 318. 
Most commentators have recognized that for the jury to intelligently use the alternative penalty statutes it must have before it the same type of evidence as does a judge or agency in non-capital cases. ${ }^{15}$ However, except in the three states which have enacted the split trial procedure for determining punishment in a capital case, the jury must determine in a single verdict in a single proceeding both the guilt or innocence of the accused and the punishment to be imposed. ${ }^{16}$ To avoid the very real danger that evidence relevant solely to punishment would, if admitted, influence the verdict on the guilt issue, evidence of the habits and background of the accused is generally held inadmissible in the single trial situation. ${ }^{17}$ Consequently, the evidence available to the jury in determining the penalty is restricted to that otherwise admissible on the issue of guilt. ${ }^{18}$

As a result of these restrictions on the admissibility of background evidence, a jury is required to make the most crucial of decisions on only a portion of the evidence properly bearing on the issue. ${ }^{19}$ The split trial procedure is designed to escape this dilemma..$^{20}$ With the issues of guilt and punishment separated, there is no longer a reason for excluding evidence admittedly relevant to punishment. As was intended, the evidence admitted in the penalty proceeding has been as varied as the defendants and their crimes.

\section{A. Evidence in General}

There are no statutory limitations on the admissibility of evidence in the penalty trial, the legislature apparently having contenuplated a wide range of judicial discretion in determining the evidence admitted in each case. Since the

15 See, e.g., Royal Comor's on Capital Punishment, Report, CMd. No. 8932, 194-207 (1953) ; Model Penat Cone § 201.6, comment (Tent. Draft No. 9, 1959) ; Knowlton, Problems of Jury Discretion in Capital Cases, 101 U. PA. L. Rev. 1099 (1953) ; 29 J. CRn工. L. \& C. 883 (1939). Compare State v. Mount, 30 N.J. 195, 152 A.2d 343 (1959), with Ashbrook v. State, 49 Ohio App. 298, 197 N.E. 214 (1935).

16 Handler, supra note 11, at 318 .

17 Prior to the statutory separation of trials, California limited the consideration of the jury "to facts and circumstances surrounding the commission of the crime itself." Pcople v. Barclay, 40 Cal.2d 146, 252 P.2d 321 (1953); People v. Valenzuela, 7 Cal.2d 650, 62 P.2d 142 (1936). Although there are instances in nearly every jurisdiction where the range of evidence admitted has been extended to include evidence relevant solely to punishment, no single-verdict jurisdiction has a consistent policy of admission. See Handler, supra note 11, at 320 .

18 See, e.g., Commonwealth v. McNeil, 328 Mass. 436, 104 N.E.2d 153 (1952) ; State v. Mount, 30 N.J. 195, 152 A.2d 343 (1959); Modex Penat Code $\$ 201.6$, comment 5 (Tent Draft No. 9, 1959).

19 Prior to the statutory separation of trials, if the question of punishmont was tried to the court on a plea of guilty the court was allowed to consider in aggravation or mitigation matters not admissible on the issue of guilt. People v. Thomas, 37 Cal.2d 74, 230 P.2d 351 (1951) ; People v. Gilbert, 22 Cal.2d 522, 140 P.2d 9 (1943). Similarly, if the court is presently the trier of fact on the issue of penalty, the rules governing the admissibility of evidence are somewhat more liberal than if the jury is the trier of fact. Compare People v. Robillard, 55 Cal.2d 88, 358 P.2d 295, 10 Cal. Rptr. 167, cert. denied, 365 U.S. 886 (1960), with People v. Love, 53 Cal. 2d 843, 350 P.2d 705, 3 Cal. Rptr. 665 (1960).

20 The split trial procedure apparently was enacted in California in response to the promptings of the California Supreme Court. In expressly inviting a legislative solution to the problem of the scope and character of evidence pertinent to punishment, the court noted the irony of committing to the jury the responsibility of fixing the penalty in a capital case, while at the same time denying to it "the full measure of enlightenment" sought where less drastic punishments were involved. People v. Friend, 47 Cal. 2d 749, 763 n.7, 306 P.2d 463, 471 n.7 (1957). 
sole issue is life or death, the scope of relevant inquiry is broad; nonetheless, expeditious judicial administration and the need to avoid prejudice to the convicted defendant require that it not be unlimited. One major limitation is that section 190.1 has been construed as allowing only "competent" evidence to be presented to a jury. ${ }^{21}$ For example, all hearsay evidence must be stricken from probation reports, prison disciplinary records or Adult Authority case summaries before the records may be placed before the jury. ${ }^{22}$ Although these records are admissible in toto when a court or the Adult Authority inakes a determination of probation or parole, the rationale for exclusion of hearsay statements at the penalty trial apparently is based on the assumption that juries cannot properly evaluate such evidence. Despite the questionable validity of this assumption, the court has been reluctant to abandon it where the issue is life or death.

When otherwise "competent" evidence is involved, there remains the problem of determining its relevancy. Generally, trial courts are to exercise the same balancing technique they do in other trials. Evidence is to be excluded if its probative value is outweighed by its tendency to unduly protract the trial, to confuse the essential issue, or to inflame and prejudice the minds of the jurors against the defendant. ${ }^{23}$ When evidence is offered to show, for example, the mental condition of the defendant or his general background, the problem is similar to that faced by courts in other trials. The fact to be proved itself provides soine standard for determining the relevancy of the offered evidence. ${ }^{24}$ In these types of situations, the supreme court usually has accorded great weight to the discretion of the trial court; errors, if any, usually have been deemed nonprejudicial. $^{25}$

The greatest difficulty facing the courts, however, is determining whether offered evidence is relevant to a choice between life imprisonment and death. The unique nature of the sentencing inquiry continually requires trial courts to weigh the probative value of allegedly inflammatory evidence against its bearing on the several objectives of punishment. In order to decide intelligently whether to admit or exclude this evidence, the trial court must possess a coherent theory of punishment. Reference to the statute, which merely provides for a wide range of evidence, is unavailing. Compounding the problem is the controversial and elusive nature of the objectives of criminal punishment. ${ }^{26}$ It is here that the

21 People v. Hamilton, 60 A.C. 51, 75-77, 383 P.2d 412, 426-27, 32 Cal. Rptr. 4, 18-19 (1963); People v. Purvis, 52 Cal.2d 871, 883-84, 346 P.2d 22, 29 (1959).

The rule apparently will be different in New York since its statute provides in part: "Any relevant evidence, not legally privileged, shall be received regardless of its adinissibility under the exclusionary rules of evidence." N.Y. PENAL LAw 1045-a. The statute became effective in July, 1963, but apparently has not as yet been construed in any case.

22 Compare People v. Hamilton, supra note 21 at 77, 383 P.2d at 427, 32 Cal. Rptr. at 19 and People v. Purvis, supra note 21, with People v. Lopez, 60 A.C. 171, 202, 384 P.2d 16, 34, 32 Cal. Rptr. 424, 442 (1963).

23 See, e.g., People v. Purvis, 56 Cal.2d 93, 362 P.2d 713, 13 Cal. Rptr. 801 (1961); Yeuple v. Love, 53 Cal. 2d 843, 350 P.2d 705, 3 Cal. Rptr. 665 (1960). See generally McCorAICK, EVIDENCE chs. 16, 17 (1954).

34 Cf. MCCorarick, Evidence 319 (1954).

25 See. e.g., People v. Moya, 53 Cal.2d 819, 350 P.2d 112, 3 Cal. Rptr. 360 (1960).

" The modern view is that punisliment appropriately serves one or more of the followmb uurposes: deterrence of the offender and other prospective offenders from crime, rehabilitauis of the defendant, and the protection of society. See generally HALI, GENERAL PRINCIPLES

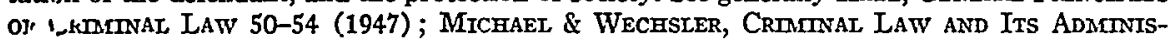


failure of the legislature to more precisely define the theory or the scope of the penalty trial has proved a serious defect which can be remedied, if at all, only by judicial action. The absence of legislative standards for the admissibility of evidence has compelled the supreme court to attempt to fill the void.

In People v. Love, ${ }^{27}$ for example, the supreme court held erroneous the admission of inflammatory evidence which could have been relevant only to retribution for the enormity of the crime. ${ }^{28}$ The court reiterated previously expressed doubts whether retribution is today a dominant objective of criminal punishment. ${ }^{29}$ The decision in Love indicated, not that retribution is a wholly inappropriate consideration in the selection of punishment, but that a fair penalty trial requires that little weight be given to retribution in determining the admissibility of evidence to a jury. More important, the decision illustrates that in order to formulate meaningful evidentiary pohicies, the court must delimit, either expressly or by implication, those factors which it beheves should influence the jury in its selection of the penalty. The decisions on the admissibility of evidence are coherent only if viewed as part of a larger search, perhaps in vain, for a rational basis for determining the fate of a convicted defendant. Whatever the expressed grounds for decision, the concern of the California Supreme Court for a more rational, less emotional sentencing inquiry is apparent in its treatment of three specific types of evidence: the merits of the death penalty as a penal sanction, the probable future disposition of the defendant if he is sentenced to life imprisonment, and the other criminal activities of the defendant.

\section{B. Death Penalty as a Deterrent to Crime}

Evidence offered to prove the relative efficacy of the death penalty as a deterrent to crime, or its social desirability or its moral permissibility, is totally excluded from the penalty proceeding. ${ }^{30}$ Since no evidence is admissible on the

Tration 6-17 (1940); TAppan, Crame, Justice and Correction 237-72 (1960). There is a controversy over the continued propriety of retribution or vengence as an appropriate objective of criminal punishment. See Williams v. New York, 337 U.S. 241, 248 (1949) ; MICHAEL \& WeCHSLER, op. cit. supra at 6-11. See also cases cited note 29 infra. Compare People v. Harmon, 54 Cal. 2d 9, 351 P.2d 329, 4 Cal. Rptr. 161 (1960), with People v. Oliver, 1 N.Y.2d 152,151 N.Y.S.2d 367,134 N.E.2d 367 (1956). Adding to the controversy is the fact that none of the theories by which the death penalty is justified can be factually substantiated, nor disproved. See Royal Comm's on Capitaz Punishment, Report, CMd. No. 8932, 17-24 (1953); Selitn, The Death Penalty 19-63 (1959).

2753 Cal. 2d 843, 350 P.2d 705, 3 Cal. Rptr. 665 (1960).

$28 I d$. at 856,350 P.2d at 713,3 Cal. Rptr. at 673 . Evidence was introduced at the penalty phase solely to show that the defendant's victim had died in unusual pain. The court hcld that the introduction of this evidence was prejudicial error because there was no evidence to show that the pain was intentionally inflicted, and pain not intentionally inflicted is relevant only to the extent that retribution for the evil done is a primary purpose of punishment, a doubtful proposition in California. In any case, said the court, even if the pain were deemed relevant, it was error to permit the particular mode of proof here employed-photographs of the expression of the face in death and a tape recording of the victim's dying groans. Inflammatory evidence, even if relevant, should be excluded if it can be presented in a less inflammatory inanner. Here a doctor had already been permitted to testify that the victim dicd in extreme pain.

29 Id. at 856 n.3, 350 P.2d at 713 n.3, 3 Cal. Rptr. at 673 n.3. See People v. Brust, 47 Cal. $2 \mathrm{~d}$ 776, 791 n.8, 306 P.2d 480, 488 n.8 (1957); People v. Friend, 47 Cal.2d 749, 766 n.8, 306 P.2d 463,474 n.8 (1957).

30 People v. Love, 56 Cal. 2d 720, 726, 366 P.2d 33, 35, 16 Cal. Rptr. 777, 779, rehearing denied, id. at 748, 366 P.2d at 809, 17 Cal. Rptr. at 481 (1961). Love held that the trial court properly dismissed defendant's attempted subpoena of Governor Brown and Warden Duffy 
question, and the deterrent effect of the death penalty is not a matter of common knowledge, argument on the question is not permitted. ${ }^{31}$ The rationale for exclusion was given in People v. Love: simce the legislature has expressed no preference for either penalty, leaving the choice in each case to the discretion of the trier of fact, there is no legislative pronouncement that capital punishment is a more effective deterrent to crime than life imprisonment. Such a determination, if it is to be made at all, should be made by the legislature.

Evaluation of the court's position in excluding such evidence and limiting argument need not depend, however, on whatever supposed motives we ascribe to the legislature in retaining the death penalty. The basic purpose of the statutory procedure for sentencing in capital cases is that the decision be an individual one, based upon the character of the defendant and the degree of his moral turpitude, as judged by a jury of his peers. While each juror's final decision will mevitably be influenced by his own view of the death penalty, the social justification for the death penalty is not a matter that can be resolved by a jury, and should not be weighed in making individual decisions. The danger in stressing the deterrent effect of the death penalty-a proposition that has no conclusive factual support ${ }^{32}$-is that the defendant might be sacrificed solely because of the broader social policy, the circumstances of his crime notwithstanding.

\section{Evidence of Parole Practices}

Until very recently, California allowed a full inquiry at the penalty trial into the practical ramifications of a life sentence. On the theory that an intelligent selection of pumishment required knowledge of the potential consequences of a life sentence, the trial court was permitted to instruct the jury as to the length of time in prison which might result from a life sentence. ${ }^{33}$ Expert evi-

for the purpose of eliciting their views on capital punishment. Accord, People v. Shipp, 59 Cal. 2d 845, 382 P.2d 577, 31 Cal. Rptr. 457 (1963) (defense counsel attempted to read newspaper article about the death penalty); People v. Lane, $56 \mathrm{Cal} .2 \mathrm{~d} 773,366$ P.2d 57, $16 \mathrm{Cal}$. Rptr. $\$ 01$ (1961) (defense called prison chaplain) ; People v. Kidd, 56 Cal. 2d 759, 366 P.2d 49, 16 Cal. Rptr. 793 (1961) (defense called two members of legislative committee on capital punishnient).

31 People v. Love, supra note 30 at 729-33, 366 P.2d at 37-40, 16 Cal. Rptr. at 781-84; People v. Ketchel, 59 Cal. 2d 503, 381 P.2d 394, 30 Cal. Rptr. 538 (1963). Such an argument will be prejudicial error when there is "an emphatic presentation of the unproved contention of the superiority of the death penalty." Id. at 539, 381 P.2d at 413, 30 Cal. Rptr. at 557. The prosecution may, however, continue to argue that the facts of the case at hand make it a proper case for the imposition of the death penalty. Even the contention that the death penalty is a more effective deterrent will not be grounds for reversal when made in response to a contrary argument by defense counsel. People v. Pike, 58 Cal. 2d 70, 372 P.2d 656, 22 Cal. Rptr. 664 (1962). Other cases holding that reference to the effect of the death penalty is error, but not prejudicial are: People v. Garner, 57 Cal. 2d 135, 367 P.2d 680, 18 Cal. Rptr. 40 (1962) ; People v. Imbler, 57 Cal. 2d 89, 371 P.2d 304, 21 Cal. Rptr. 568 (1962).

32 See Selins, The Death Penalty 19-63 (1959); Bennett, Delaware Abolishes Capital Punishment, 44 A.B.A.J. 1053 (1958); Savitz, A Study in Capital Punishment, 49 J. CRTr. L., C. \& P.S. 338 (1959). For an excellent summary of the many difficulties inherent im measuring the efficacy of the death penalty as a deterrent, see TAPPAN, op. cit. supra note 26, at 253-54.

33 See, e.g., People v. Love, 56 Cal. 2d 720, 366 P.2d 33, 16 Cal. Rptr. 777 (1961); People v. Scott, 53 Cal. 2d 558, 348 P.2d 882, 2 Cal. Rptr. 274 (1960) ; People v. Ward, 50 Cal. 2d 702,328 P.2d 777 , cert. denied, 359 U.S. 945 (1958). An imstruction that the defendant was eligible for parole after the statutory minimum of seven years (CAz. PEN. CoDE $\$ 3046$ ) was 
dence was admissible as to the likely parole treatment the defendant would receive in view of the policies of the parole authorities, the nature of the crime and the defendant's past record. ${ }^{34}$ Statistical evidence was admissible to show the maximum, minimum and average terms actually being served by prisoners under bife sentences. ${ }^{35}$

In the recent case of People $v$. Morse, ${ }^{36}$ the supreme court reversed its previous position and held that the possibility that a defendant sentenced to life imprisonment might be paroled ${ }^{37}$ is not a proper consideration in the jury's selection of punishment. ${ }^{38}$ While many reasons were given for the decision, all seem to stem from the basic proposition that allowing the jury to consider the possible future release of a defendant is an unwarranted infrimgement of powers and responsibilities vested by the legislature in the Adult Authority. ${ }^{30}$ There-

proper where there was no evidence of Adult Authority practices. People v. Friend, 47 Cal. 2d 749, 754-55, 306 P.2d 463, 466 (1957). Where evidence of the practices of the Adult Authority was introduced, indicating that the defendant would be required to serve additional time before consideration for parole, the instruction had to be qualified by reference to this evidence. People v. Jackson, 59 Cal. 2d 375, 379 P.2d 937, 29 Cal. Rptr. 505 (1963).

34 See, e.g., People v. Purvis, 52 Cal. 2d 871, 884-85, 346 P.2d 22, 28 (1959). The major limitation imposed on the information with respect to parole was that it had to relate to persons in substantially the same position as the defendant. Id. at 886, 346 P.2d at 28. For cxample, the parole records of offenders convicted of crimes other than murder were not admissible on the penalty trial of an offender convicted of murder. People v. Moya, 53 Cal.2d 819, 350 P.2d 112,3 Cal. Rptr. 360 (1960). And when the sole issue was the penalty following a guilty plea to first degree inurder and kidnapping with bodily harm, and the court instructed the jury that the defendant could be paroled in seven years, it was reversible error to fail to tell the jury that the defendant could not be paroled under any circumstances on the kidnapping counts (CAL. Pen. Code § 209). People v. Seiterle, 56 Cal. 2d 320, 363 P.2d 913, 14 Cal. Rptr. 681 (1961).

35 See, e.g., People v. Purvis, 60 A.C. 361, 384 P.2d 424, 33 Cal. Rptr. 104 (1963). In Purvis the supreme court expressed doubt about the reliability of the statistics generally employed for this purpose. Apparently the statistics did not include the time being served by those prisoners who had not been paroled, and therefore were misleading.

3660 A.C. 613, 388 P.2d 33, 36 Cal. Rptr. 201 (1964).

37 In some classes of offenses, the legislature has expressly removed the power to parole by providing life imprisonment without possibility of parole as the sole alternative to the death penalty. CAI. PEN. CODE $\$ \$ 209$ (kidnapping with bodily harm), 219 (trainwrecking where no person suffers harm), 4500 (assault by prisoner serving a life sentence where victim does not die within a year and a day, the alternative being life without possibility of parole for nine years). Otherwise, the legislature has repeatedly resisted attempts to add life imprisonnint without parole either as a third alternative for first degree murder or as a substitute for the death penalty. See, e.g., S.B. 81, Reg. Sess. (1963); A.B. 2832, Reg. Sess. (1961) ; S.B. 1, 2d Extrd. Sess. (1960). A life sentence without possihility of parole is opposed by advocates of the death penalty as an ineffective deterrent, and by those opposed to the death penalty as taking no account of the rehabilitation of the offender. Both sides often mention the effect of such a sentence on prison morale and the safety of prison employees. See Hearings Before the Senate Committee on Judiciary on Senate Bill No. 1, 2d Extrd. Sess. (1960). Another possible objection to life without parole as a third alternative is that in difficult cases it might represent for the jury "the easy way out."

38 This position accords with what is now the majority position in the United States. See, e.g., State v. White, 27 N.J. 158, 142 A.2d 65 (1958); Jones v. Commonwealth, 194 Va. 273, 72 S.E.2d 693 (1962). See also Annot., 35 A.L.R.2d 769 (1954); Comment, 15 StAN. L. REv. 349 (1963).

39 The power to parole is vested by the legislature in the Adult Authority, whose seven members are appointed by the Governor with the advice and the consent of the senate. CAr. PEN. CODE $\$ \S 3040,5075$. Its declared policy is to foster rehabilitation and restore to society prisoners eligible for parole when investigation indicates that both society and the prisoner will benefit. Calmornia Adult Authority, Princtples \& Program 11-12 (1952). 
fore, instructions, evidence and argunent which place this issue before the jury will no longer be allowed. The jury may not "attempt to appraise whether at some future date the Adult Authority may inproperly release the defendant or speculate as to when he might be released." tion by the jury, which might follow complete silence on the parole question, ${ }^{41}$ the Morse court realistically offered a model instruction desigued to put the Inatter of parole in its proper perspective. The jury may be informed of the statutory power to parole but must be specifically instructed to disregard the issue, on the assumption that the designated authority will carry out its functions in a responsible manner. ${ }^{42}$

The previous treatment of the parole issue had injected into the penalty proceedings a practice which at best was confusing and tine consuming. To the extent that this practice influenced the jury to select the harsher penalty because it feared that defendant might someday be released, the practice was irrational. First, the jury had to conclude that the defendant would not respond to the prison rehabilitative process. This conclusion is difficult enough for experts after observing the defendant durmg his period of incarceration; for a jury, lacking expertise, and able to look only into the future, it is mere speculation. ${ }^{43}$ Secondly, having concluded that the defendant would not in the future be fit for release into society, the jury had to conclude that the parole authorities nevertheless would parole him. While the chance of error by the Adult Authority is of justifiable concern, it is a matter for legislative correction and not a proper consideration in selecting punishment for a particular defendant.

The major impact of Morse on the penalty proceeding is its re-emphasis of the essentially individual focus of the punishment decision. The jury should not decide general questions of the administration of criminal justice, but rather "whether the individual should be permitted to live upon the basis of a coinplete and careful analysis of that person as a human composite of emotional, psychological and genetic factors." 44 No inatter how extensive the evidence, the probability of future release is nothing more than a prediction which ignores the individual basis for parole decisions. Like the decisions excluding evidence and argument on the value of the death penalty as a deterrent, Morse tends to

4060 A.C. at 629,388 P.2d at 43,36 Cal. Rptr. at 211.

41 The usual justification for allowing comment on parole is that the existence of the parole power is a matter of common knowledge and therefore the jury should be given correct information to prevent uninformed speculation. See Moder PeNAI Code \$201.6, comment 5 at 77 (Tent. Draft No. 9, 1959). Cases are legion in which, im the absence of comment by either the trial court or counsel, the jury has interrupted its deliberations to inquire of the court about the possibility of the defendant's parole if a life sentence is imposed. See Annot, 35 A.L.R.2d 769 (1954).

4260 A.C. at 630,388 P.2d at 44,36 Cal. Rptr. at 211 (1964).

${ }^{43}$ See Hayden, Criminal Law \& Procedure, 13 Rutaers L. Rev. 105, 125 (1958): "That ... [the selection of penalty] should not be influenced by an unskilled consideration and evaluation of whether or not defendant is presently or ever will be a proper subject for parole goes without saying." Cf. Bennett, Individualizing the Sentencing Function, 27 F.R.D. 359, 365 (1961): "No one realizes more fully than a judge that it is virtually impossible on sentencing day to say just how long a given defendant should remain in prison. It can best be determined ... when passions have cooled and when the prisoner himself has demonstrated the reasons why he should or should not remain in prison."

4460 A.C. at 629,338 P.2d at 43,36 Cal. Reptr. at 211 (1964). 
further define, by restriction to be sure, those considerations which are most capable of evaluation by a jury. ${ }^{45}$

\section{Evidence of Other Crimes}

To avoid convicting a defendant because of his bad character, evidence of crimes other than those alleged in the indictment generally is held inadmissible on the issue of guilt. ${ }^{46}$ With that danger removed by the separation of trials, and with bad character directly in issue at the penalty phase, evidence of the defendant's other criminal activities is admitted as pertinent to his background or in aggravation of the penalty. ${ }^{47}$ Although the exact scope of the rule is unclear, generally any crime committed by the defendant, whether or not resulting in a prior conviction, ${ }^{48}$ may be proved in the penalty proceeding. ${ }^{40}$ Two distinct situations should be noted. In the first situation the defendant has been convicted of another offense; the issue in the penalty trial is then whether additional evidence relating to the circumstances surrounding that crime may be introduced. ${ }^{50}$ In the second, the defendant has engaged in other criminal activities for which he has not been convicted; here the issue is whether and how these crimes may be proved in the penalty trial. ${ }^{51}$

When the defendant previously has been convicted of a particular crime, the bare record of that conviction inay not adequately apprise the jury of the relevant facts surrounding its commission. On this basis it is held that the doctrine of res judicata does not preclude inquiry into circumstances surrounding the commission of another crime; ${ }^{52}$ furthermore, the jury need not be bound

45 The trial court in Morse had also given the standard instruction that "the law of this State provides that a defendant sentenced either to death or life imprisonment may be pardoned or have his sentence reduced by the Governor .... A trial judge may also reduce the penalty from death to life imprisonment." These instructions were also held erroncous, on the ground that their "impact ... must necessarily weaken the jury's own sense of responsibility." 60 A.C. at 634,338 P.2d at $47,36 \mathrm{Cal}$. Rptr. at 212. For similar holdings, see People v. Hines, ...... A.C. ......, 390 P.2d 398, 37 Cal. Rptr. 622 (1964) ; People v. Terry, ...... A.C. ......, 390 P.2d 381, 37 Cal. Rptr. 605 (1964) ; People v. Linden, 52 Cal. 2d 1, 26-27, 338 P.2d 397, 415 (1959).

46 Michelson v. United States, 335 U.S. 469 (1948); 1 WIGMORE, Evinence $\& 57$ (3d ed. 1940, Supp. 1962). The rule is riddled with exceptions. For exaniple, evidence of other crimes may be admitted if it has an independent relevance to the issue of guilt, such as to show nuotive or intent. 2 WIOMORE, op. cit. supra $\$ 304$. For the California statement of the rule and its exceptions, see People v. Peete, 28 Cal.2d 306, 169 P.2d 924 (1946), 35 CArT. L. REv. 131 (1947). See generally McCormick, EvIDENCE 157 (1954); 2 UNDERHII, CrRmanal EviDENCE $\S \S 205-11$ (rev. ed. 1956).

47 People v. Robillard, 55 Cal. 2d 88, 358 P.2d 295, 10 Cal. Rptr. 167 (1960); People v. Jones, 52 Cal. 2d 636, 343 P.2d 577 (1959).

48 Compare People v. Bentley, 58 Cal.2d 458, 374 P.2d 645, 24 Cal. Rptr. 685 (1962), with People v. Purvis, 52 Cal. 2d 871, 346 P.2d 22 (1959). Such evidence must in either crse be competent. For exaniple, if the defendant has extrajudicially confessed to a certain crime, his admissions are admissible but only after independent proof of the corpus delecti. People v. Hines, ..... A.C. ......, 390 P.2d 398, 37 Cal. Rptr. 622 (1964); People v. Hamilton, 60 A.C. 51, 76,383 P.2d 412, 427, 32 Cal. Rptr. 4, 19 (1963). One inethod of establishimg a corpus delecti is by eye-witness testimony relating to the other crime. See, e.g., Pcople v. Bentley, supra.

49 Pennsylvania limits evidence on the punishment issue to the official record of prior convictions and the admissions and confessions of the defendant. See Commonwealth v. McCoy, 405 Pa. 23, 172 A.2d 795 (1961); Commonwealth v. Rucker, 403 Pa. 262, 168 A.2d 732, cert. denied, 368 U.S. 868 (1961).

50 See text accompanying notes 52-64 infra.

51 See text accompanying notes 65-74 infra.

52 People v. Ketchel, 59 Cal. 2d 503, 542, 381 P.2d 394, 415, 30 Cal. Rptr. 538, 559 (1963) ; People v. Purvis, 52 Cal.2d 871, 881, 346 P.2d 22, 27 (1959). 
by a prior verdict but may independently evaluate the evidence of that crime..$^{53}$ In People v. Purvis, ${ }^{54}$ for example, defendant had been convicted of second degree murder of his wife, sentenced and paroled, and subsequently convicted of the first degree murder of a paramour. In the penalty trial for the second murder, the prosecution was allowed to prove not only the fact of the prior conviction, but also the circumstances surrounding the earlier offense by the use of eyewitness testimony. On appeal, both the admission of the evidence and the manner of proof were approved, the court emphasizing that an intelligent evaluation of the prior conviction required that the jury be informed of the details of that crime. Since the two crimes were markedly similar, the jury might independently conclude, witliout being bound by the finding implicit in the prior conviction of second degree murder, that the defendant had twice committed premeditated murder. ${ }^{55}$ In Purvis, the court said the rule was to work both ways: the defendant could show extenuating or mitigating circumstances surrounding the commission of another crime, or even his innocence of that crime..$^{56}$

Although some critics fear that there is no effective way to limit evidence of the circumstances surrounding a defendant's other crimes, ${ }^{57}$ there seems hittle justification for excluding it altogether. It would appear that a careful weighing of the probative value of the evidence in relation to the issue of penalty can prevent abuse of the practice. Relevant evidence tends to establish conduct of the defendant which may appropriately influence the selection of penalty; the defendant's conduct may be relevant regardless of its characterization, in legal terminology, as a particular crime or degree of crime. An mquiry into that conduct is consistent with the complete investigation permitted into other aspects of the defendant's background and history. On the other liand, no useful purpose is served by allowing rehtigation of issues collateral to the conduct of the defendant, simply to impeach the legal validity of a prior verdict. Explicit recognition of this distinction provided the basis for evaluating certain evidence offered by the defendant in People v. Terry. ${ }^{58}$ At Terry's penalty trial, the prosecution introduced defendant's 1958 conviction for sodomy under Penal Code Sections 286 and 288. The defendant offered to show that the former trial had been conducted on the basis of transcripts, and that instead of producing the victims as complaining witnesses, the prosecution read their testimony from the transcript of the preliminary hearing. The trial court's rejection of this offer of proof was uplield by the supreme court. ${ }^{59}$ While the defendant was properly

53 People v. Purvis, supra note 52 at 882,346 P.2d at 28.

5452 Cal. 2d 871,346 P.2d 22 (1959).

65 Id. at 882,346 P.2d at 28 .

$56 \mathrm{Ibid}$. Whatever the rule, the practice seems to favor the prosecution, for a defendant who has been previously convicted will rarely have substantial evidence in mitigation of that crime. One of the infrequent instances in which the defendant has introduced such evidence is found in People v. Terry, ...... A.C. ......, 390 P.2d 381, 37 Cal. Rptr. 605 (1964). One Wilson was permitted to testify that he told the truth on the witness stand when, at a previous trial in which Terry was convicted of sex violations, he testified to Terry's innocence.

57 "To permit a jury to retry cases of former convictions in order to consider the propriety of the conviction, or of the sentence, or possible mitigating circumstances would befog and make trials almost interminable and practically and legally, be utterly ridiculous." Commonwealth v. Rucker, 403 Pa. 262, 268, 168 A.2d 732, 734 (1961) (expressly disavowing the rule of People v. Purvis, 52 Cal.2d 871, 346 P.2d 22 (1959)).

58 ..... A.C. ......, 390 P.2d 381, 37 Cal. Rptr. 605 (1964).

6937 Cal. Rptr. at 613-14. 
allowed to produce evidence of his innocence of those crimes (testimony of a codefendant), he could not attack "the legality of ... [a prior] conviction or the process of its adjudication." 60

The purpose of admitting evidence of the circumstances surrounding the defendant's other crimes presumably is to enable the jury to render an intelligent and informed decision on the penalty issue. If the jury is not to be restricted to the mere fact of a previous conviction, the question again arises as to what additional evidence should be received. Since defendants rarely have substantial evidence in mitigation of prior crimes, the issue most often is the scope of inquiry allowed the prosecutor. In the Purvis ${ }^{61}$ case and others following it, the supreme court held that detailed evidence was properly admitted as relevant to determining whether the crime for which the defendant was being sentenced might possibly recur. ${ }^{62}$ The court reasoned that the jury might infer that a bife sentence, with the concomitant possibility of parole, would not fully protect society from future harm by the defendant. No evidence seems more relevant to the possible recurrence of the defendant's crime, and thus to the protection of society, than that on another occasion he committed substantially the same crime under markedly similar circumstances. On the other hand, in the absence of a marked similarity in the crmies involved, going beyond the official record of judgment is of doubtful efficacy in aiding the jury. The additional evidence will be only cumulative, and it may be highly prejudicial. With this himitation, the Purvis theory appears sound. It is possible, however, that subsequent decisions have undermined the theoretical justification for the Purvis approach. Under Morse, ${ }^{63}$ juries are required to assume that the Adult Authority will adequately protect society by retaining defendants sentenced to hife imprisonment until they can safely be released. The only remaining justifications for admitting this type of evidence as an aggravating circumstance might be a concern for the defendant's mental condition or his disdain for society's laws. The bare fact that he killed twice would seem sufficient to illustrate this point; detailed evidence would appear to add bittle. When the defendant seeks to go beyond the record (assuming his evidence is not objectionable as an attempt at total rehtigation of guilt), a broader approach seems justified. When only the bare fact of a prior conviction is introduced, the conduct attributable to the defendant can only be viewed by the jury as it is described in the imprecise and condemnatory language of a penal statute. If the prosecution is to benefit from introduction of defendant's entire criminal record, with the natural inference that he engaged in the activities represented by that record, the defendant should be allowed to show any extenuating circumstances that might have existed. ${ }^{64}$

The California rule permitting evidence of other criminal conduct for which the defendant has not been convicted was the subject of consideration in the recent case of People v. Terry. ${ }^{65}$ That case indicates that a prosecutor desirous

60 Ibid. In dictum, the court made the rule broad enough to preclude an attack based on an "alleged failure of due process." Query whether this language would preclude an attack on the jurisdiction of the court in the constitutional sense-for example, a coerced confession or no attorney.

61 People v. Purvis, 52 Cal.2d 871, 346 P.2d 22 (1959).

$62 I d$. at 882,346 P.2d at 28.

63 People v. Morse, 60 A.C. 613, 388 P.2d 33, 36 Cal. Rptr. 201 (1964).

${ }_{64}$ Cf. People v. Terry, ...... A.C. ......, 390 P.2d 381, 37 Cal. Rptr. 605 (1964).

65 ..... A.C. ......, 390 P.2d 381, 37 Cal. Rptr. 605 (1964). 
of introducing such evidence must prove all of the elements of those offenses in the penalty proceeding. Terry held it was error to allow the introduction of an information for the purpose of proving that the defendant had committed the crime alleged therein. ${ }^{6}$ The basis for the holding was that evidence that the defendant was previously the subject of prehminary criminal proceedings is more prejudicial than probative, because a jury has not "found beyond a reasonable doubt that the defendant has committed the alleged offense."67 If, as the court indicated, the defendant in a penalty trial is entitled to this "safeguard,"68 the prosecution will be able to show that the defendant committed another crime only by a record of prior conviction, or by independent proof, presumably beyond a reasonable doubt, ${ }^{69}$ at the penalty trial.

However, this does not mean that prior crimmal proceedings resulting in anything other than a conviction will prevent proof of the alleged offense in the penalty trial. The Terry rule simply prevents use of preliminary criminal proceedings to prove the actual commission of the crime. ${ }^{70}$ This rule balances two commendable objectives. Since it is unrealistic to suppose that every failure to obtain a conviction of guilt represents a finding of innocence of the alleged conduct, it would be inconsistent with the broad investigation into defendant's non-criminal conduct to foreclose inquiry into potentially "criminal" conduct. On the other hand, fairness dictates that the defendant not be subject to a finding that he committed other criminal acts on the very speculative basis that he was arrested, or that an information was filed against him.

Another application of this approach arises when the defendant has been subject to prior criminal proceedings which resulted in a final judgment of acquittal. In People v. Griffin, ${ }^{71}$ decided a year before Terry, defendant had committed murder in conjunction with an attempted rape. To escape apprehen-

66390 P.2d at 389,37 Cal. Rptr. at 613.

67 Ibid. (Emphasis added.) The court also found that the information constituted incompetent hearsay evidence, but did not rest its decision on that ground. See note 21 supra.

68 Ibid.

${ }^{69}$ In a footnote, the court said that the "defendant should not be subject to a finding of a jury that he committed prior crimes unless his commission of such prior crimes has been proven beyond a reasonable doubt." 390 P.2d at 389 n.8, 37 Cal. Rptr. at 613 n.8. This conflicts, however, with the present rule that neither the prosecution nor the defendant has a burden of proof in the penalty trial. Terry left this conflict unresolved. See text accompanying notes 95-106 infra. The rather cryptic language of the footnote is susceptible of another interpretation: no prior or subsequent crimes may be proved in the penalty trial unless a jury has already found beyond a reasonable doubt that the defendant committed such a crime. If this is what the court means, then unless the defendant has previously been convicted so that an abstract of the former judgment is available as evidence, such a crime may not be proved in the penalty trial. This interpretation would deny relevant sentencing information to the jury; however, it is unlikely that the court means to work such a fundamental change in the scope of evidence permitted. Such a rule would be inconsistent with the evidence allowed in the following cases, all of wbich permitted proof of other offenses for which the defendant had never been previously tried or convicted: People v. Griffin, 60 A.C. 129, 383 P.2d 432, 32 Cal. Rptr. 24 (1963); People v. Ketchel, 59 Cal. 2d 503, 381 P.2d 394, 30 Cal. Rptr. 538 (1963); People v. Bentley, 58 Cal. 2d 458, 374 P.2d 645, 24 Cal. Rptr. 685 (1962) ; People v. Jones, 52 Cal. 2d 636, 343 P.2d 577 (1959). All of these cases were cited in the Terry opinion, however, as "guidehines" for determining the admissibility of evidence. 390 P.2d at 386,37 Cal. Rptr. at 611 .

70 The court has also disapproved as too speculative testimony that the defendant had been arrested; no charges had been filed and he had been released without further action. People v. Hamilton, 60 A.C. 51, 78, 383 P.2d 412, 428, 32 Cal. Rptr. 4, 20 (1963).

7160 A.C. 129, 383 P.2d 432, 32 Cal. Rptr. 24 (1963). 
sion the defendant crossed the border into Mexico, where he allegedly perpetrated a rape similar to the one involved in the killing. In the penalty trial following the conviction for first degree murder, witnesses from Mexico were allowed to testify as to the alleged rape there. On appeal from the death penalty, the court approved the admission of such evidence, even though defendant had been arrested, tried, and acquitted in Mexico prior to his apprehension by California authorities. ${ }^{72}$ While Terry does not indicate that an acquittal precludes independent proof of the alleged offense in the penalty trial, it does indicate that the Griffin approach cannot stand without an important qualification. Since Griffin was acquitted in the Mexico trial, and since at the time of his penalty trial there was no case supporting the view that other crimes had to be proved beyond a reasonable doubt, or by any quantum of proof whatsoever, ${ }^{73}$ Griffin was deprived of the very safeguard which the Terry court now deems necessary to protect the defendant from undue prejudice. Were the case to arise today, Terry would seem to impose as a minimum requirenient that proof in the penalty trial of a crime for which the defendant was acquitted be beyond a reasonable doubt. ${ }^{74}$

\section{PROBLEMS OF JURY DISCRETION}

When the legislature altered the sentencing procedure to be followed in a capital case, it did not see fit to provide standards for the ultimate resolution of the penalty issue by the deciding body. ${ }^{75}$ Apparently agreeing with the view that the relevant considerations in a given case are "too complex to be expressed within

72 Id. at I35-37, 383 P.2d at $436-37,32$ Cal. Rptr. at 28-29.

${ }^{73}$ See text accompanying notes 95-109 infra.

74 See People v. Terry, ....... A.C. ......, 390 P.2d 381, 37 Cal. Rptr. 605 (1964). In Terry's penalty trial, the prosecution was allowed to introduce a certified copy of defendant's armed robbery conviction in Oklahoma, for which offense Terry subsequently had been pardoned. The court held that under the full faith and credit clause of the United States Constitution (art. IV, § 1), Cahifornia must defer to Oklahoma's treatment of a pardoned defendant as one not convicted of a crime. Since the purpose of introducing the conviction was to prove that the defendant had committed armed robbery, the court said that the evidence should have been excluded. This situation is clearly distinguishable from Grifin, since an acquittal obviously would not be introduced to prove the commission of a crime. The Griffin issue would have arisen, however, if witnesses to the alleged Oklahoma robbery had been called to testify in Terry's penalty trial. In the future the court might treat an acquittal by a court of competent jurisdiction as conclusive and exclude all such evidence relating to that offense from the penalty trial. The Griffin court justified the testimony on the basis that an acquittal is "merely an adjudication that the proof ... was not sufficient to overcome all reasonable doubt of ... [the accused's] guilt." 60 A.C. at 137, 383 P.2d 436, 32 Cal. Rptr. at 29. But Terry indicates that unless the proof is that strong it should not be considered. Allowing a retrial of an acquittal, even with the safeguard of proof beyond a reasonable doubt, raises the possibihty that a defendant might be seriously prejudiced by his inability to again match resources with the state. It is true that there is no redetermination of criminal responsibility for the previous crime in that the defendant is not in jeopardy of suffering punishment for that offense. On the other hand, a finding by the jury that the defendant had committed the acts in qucstion might influence the jury to select the death penalty. Moreover, a later trial would inevitably suffer from a lessened ability to determine the truth.

75 A legislative directive that a particular penalty shall follow a particular finding must be distinguished from a directive that certain factors must be considered in. selecting the penalty. The former, the "categorical prerequisite," is the ambitious approach taken by the 
the limits of a simple formula,"76 the choice between life imprisonment and death was committed to the discretion of the trier of fact. ${ }^{77}$ Like the absence of statutory standards for the admissibility of evidence, this legislatively undefined "discretion" makes effective administration of the penalty statute more difficult. It is especially troublesome when the jury is the trier of fact on the punishment issue. The problem of the court can be viewed as one of preserving to the jury an unrestricted choice of punishment, while at the same time making that choice meaningful.

The trier of fact's discretion is said to be "absolute."78 This concept is derived from the pre-section 190.1 treatment of the language of section 190, which provided (prior to its 1957 amendment ${ }^{79}$ to conform with the split trial procedure) that persons convicted of first degree murder "shall suffer death or confinement in the state prison for life, at the discretion of the jury . . ."80 The leading case interpreting the section as it then stood is People v. Green, ${ }^{81}$ decided by the California Supreme Court in the year prior to the enactment of the split trial procedure. In Green the court was faced with a long line of decisions holding, in effect, that death was the primary punishment under the statute, automatically attaching on a determination of guilt. The jury's discretion was conditional; rather than selecting the punishment in the first instance, the jury could relieve the defendant from the extreme penalty only on finding extenuating or mitigating circumstances warranting the imposition of the lesser penalty. ${ }^{82}$ In Green, the court expressly overruled this he of cases, holding that an instruction embodying this hmitation was contrary to the statute. The court said that the jury must be advised unequivocally of its "absolute discretion" to select either penalty. Neither penalty is preferred by law, and the discretionary power to choose life imprisonment does not depend on a finding of mitigating circumstances, nor does the power to impose the death penalty depend on a finding of aggravating circumstances. ${ }^{83}$

Model Penal Code. Under that approach, circumstances of aggravation and mitigation are enumerated, and a finding of one of the aggravating circumstances is a prerequisite to the power to impose the death sentence. See Model Penar Code $\$ 210.6$ (Prop. Off. Draft, 1962); Model Penal Code $\$ 201.6$, comment 3, at 71-72 (Tent. Draft No. 9, 1959). For an example of the second approach, whereby certain factors must be considered in the exercise of a "legal discretion" to select either penalty, see Commonwealth v. Green, $396 \mathrm{~Pa}$. 137, 151 A.2d 241 (1959, noted, 108 U. PA. L. REv, 434 (1960). Failure to consider those factors is an "abuse of discretion" subject to appellate review. California bas taken neither position legislatively or judicially. See text accompanying notes 78-83 infra.

70 Royal Comm's on Capital Punismoment, Report, CMd. No. 8932, at 174 (1953).

77 Cat. Pan. Code \$ 190.1.

78 E.g., People v. Mason, 54 Cal. 2d 164, 351 P.2d 1025, 4 Cal. Rptr. 841 (1960) ; People v. Jones, 52 Cal. 2d 636, 648-49, 343 P.2d 577, 585 (1959). Cf. People v. Friend, 47 Cal. 2d 749, 765, 306 P.2d 463, 473 (1957).

70 Cal. Stat. ch. 1968, \&1 (1957).

80 Section 190 now provides: "At the discretion of the court or jury ... and the matter of punishment shall be determined as provided in Section 190.1 . . ." (Emphasis added.)

8147 Cal. 2d 209, 302 P.2d 307 (1957).

82 This erroneous concept originated in People v. Welch, $49 \mathrm{Cal} .174,180$ (1874), where the court interpreted $\$ 190$ as if it read "shall suffer death or (in the discretion of the jury) imprisonment . . . for life." Cases perpetuating the error included: People v. Byrd, 42 Cal. $2 \mathrm{~d}$ 200, 266 P.2d 505 (1954); People v. Williams, 32 Cal.2d 78, 195 P.2d 393 (1948); People v. Lindley, 26 Cal. 2d 780, 161 P.2d 227 (1945); People v. Kolez, 23 Cal. 2d 670, 145 P.2d 580 (1944).

83 People v. Green, 47 Cal. 2d 209, 224, 302 P.2d 307, 317 (1956). 
The immediate object of the decision in Green was to discard a judicially innovated limitation on the right of the jury to select the lesser punishnient. Requiring an affirmative finding of mitigating or extenuating circumstances, particularly when such circumstances were found only on the evidence adduced on the issue of guilt, tended to defeat the ameliorating effect of the alternative penalty provision. Viewed in this light, the result in Green was desirable. On the other hand, the concept of an "absolute discretion" raised the spectre of a jury with an arbitrary and uncontrollable sentencing power. Arguably, the lack of any standard for the exercise of the jury's discretion might prove less efficacious to a rational and consistent exercise of the sentencing power than an outright limitation, for example, that the discretion to impose hife imprisonment be exercised only on a finding of mitigating or palliating circunıstances, or, what is probably more in accord with the present view of the death penalty, a requirement that the discretion to impose the death sentence be exercised only on a finding of aggravating circumstances.84 Nevertheless, the "absolute discretion" concept has been reaffirmed repeatedly. ${ }^{85}$

The minimal consequence of absolute discretion has been that the supreme court will go to great lengths to avoid prescribing limitations on the jury's power to select either penalty. This is not to say that the court has resigned itself to a procedure which might easily become an instrument of abuse. The standards established for the admissibility of evidence clearly demonstrate the contrary. The logical role of the court and the one it has attempted to assume, is to mininize, so far as possible, the arbitrary exercise of the vast power committed to the jury. To that end, the court has allowed some measure of guidance and control, which, considered in the abstract, would seem highly inconsistent with a jury discretion said to be "absolute," "sole," or "exclusive." On the other hand, it simply cannot be proved that a man should die in the same sense that it can be proved he is guilty of a crininal act. Therefore, "extra-evidentiary" 86 considerations, such as a juror's views on the death penalty, will necessarily influence the determination of penalty. The supreme court's acceptance of this fact has limited its willingness to control jury discretion.

The concept of absolute discretion in the jury to determine punishment does not contemplate, as it has in some jurisdictions, ${ }^{87}$ that the jury may not be advised by the court as to the multifarious considerations deemed pertinent to fixmg punishment. Thus it lias been stated that the jury might be advised that in exercising its discretion it may give weight to:

... considerations of the several objectives of punishment, of the deterrence of crime, of the protection of society, of the desirability of stern retribution, or of sympathy or clemency, of age, sex, human passion, ignorance or weakness, or (if appropriate under the evidence, of illness or intoxication or provocation not sufficient to reduce

84 As the dissent in Green stated: "Should the jury be instructed in effect that it has an absolute and unbridled discretion in fixing the punishment ... or should it be instructed that its discretion is a legal discretion which may not be arbitrarily exercised?" 47 Cal. $2 \mathrm{~d}$ at 238, 302 P.2d at 326 .

85 See, e.g., cases cited note 78 supra.

86 The phrase is that of Justice Schauer in People v. Purvis, 56 Cal. 2d 93, 101, 362 P.2d 713, 718, 13 Cal. Rptr. 801, 806 (1961) (dissenting opinion).

87 See, e.g., State v. McMillan, 233 N.C. 630 , 65 S.E.2d 212 (1951) ; State v. Bunk, 4 N.J. 461, 73 A.2d 249, cert. denied, 340 U.S. 839 (1950).

t. 
the degree or class of crime), of the presumptions concerning, or possible uncertainties attaching to, life imprisonment, or of the irrevocableness of an executed sentence of death, or an apprehension that explanatory facts may exist which have not been brought to hight, or any other consideration whatever which in the light of the evidence, the duty they owe to the accused and to the state ... appears to them to be important. 88

This position is realistic. The "judgment and consciences" of a jury are useless unless exercised with some knowledge of what is generally thought relevant to the sentencing process. In facing the "grim business" of determining whether a fellow human being should live or die, jurors require and are eager to have "all the guidance the law can give them." 89 Unfortunately, the presence of the words "deterrence of crime" in the quotation above renders that particular phraseology erroneous, in light of the decisions excluding evidence and argunient on the deterrent effect of the death penalty. ${ }^{90}$ The reference to "the presumptions concerning, or possible uncertainties attaching to" life imprisonment might also be improper in light of the decision in People v. Morse, ${ }^{91}$ which held that the jury must not consider the possibility of parole of a defendant sentenced to life. Although the instruction has been used occasionally with the deletion of the phrase "deterrence of crime," and might be further revised if Morse requires it, instructions are generally confined to merely advising the jury of its absolute discretion. ${ }^{92}$ Such a practice is not conducive to intelligent sentencing. The jury in every case ought to be given at least general guidelines to aid in making a decision.

While the court has not gone so far as to say that the jury need not consider the evidence, it lias often been said that the decision need not be based on the evidence. ${ }^{93}$ If extra-evidentiary considerations are proper in the jury's selection of punishment, then a requirement that the decision be based solely on the evidence is logically precluded, at least in the sense that an apparent disregard of the evidence would be subject to judicial control. Nevertheless it may be desirable that the jury be instructed that its decision be based on the evidence presented. There is an important distinction between the freedoin to disregard facts proved and the freedon to evaluate those facts with reference to extra-evidentiary considerations, whether these considerations are prescribed or not. Only the latter is consistent with the purpose of conducting an extensive inquiry into all the facts properly bearing on punishment. Resort by the jury to the non-evidentiary factors, while necessary, is only justified as a means of evaluating the evidence. An instruction advisuig the jury that it must nuake its decision on the evidence presented might, as a practical matter, mimimize the chance that the evidence will be arbitrarily ignored. ${ }^{94}$

A necessary corollary to the concept of absolute discretion, as it has developed, is that there is no burden of proof cast upon either the People or the defendant

88 People v. Friend, 47 Cal. 2d 749, 768, 306 P.2d 463, 474-75 (1957).

89 Ibid.

90 See. e.g., People v. Lane, 56 Cal.2d 773, 366 P.2d 57, 16 Cal. Rptr. 801 (1961).

9160 A.C. 613, 388 P.2d 33, 36 Cal. Rptr. 201 (1964).

(1961).

92 See, e.g., People v. Howk, 56 Cal. 2d 687, 698, 365 P.2d 426, 431, 16 Cal. Rptr. 370,375

93 E.g., People v. Lindsey, 56 Cal. 2d 324, 363 P.2d 910, 14 Cal. Rptr. 678 (1961) ; People v. Feldkamp, 51 Cal. 2d 237, 331 P.2d 632 (1958).

94 See Knowlton, Problems of Jury Discretion in Capital Cases, 101 U. PA. L. REv. 1099 (1953). 
to show by any particular quantum of evidence what penalty should be imposed.05 Since the decision is in the absolute discretion of the jury, there is no burden of producing any evidence at all, and no consequences will follow, by law, the complete silence of either party. Inposing a burden of proof as to the penalty would require that upon the failure of proof by the party with such a burden, the alternative penalty would attach. Such a result would impose a judicial preference for one of the alternative penalties in the same manner as did the decisions overturned by People v. Green. ${ }^{96}$

There is a difference, however, between a burden of proof as to the penalty to be imposed and a burden of proof on facts in the penalty trial. Yet the court has held it proper to refuse instructions to the effect that the jury must consider only those facts in aggravation that have been proved by the prosecution by a preponderance of the evidence. ${ }^{97}$ In upholding the refusal of such instructions, the sole ground advanced is the jury's absolute discretion to select the punishment. It should be noted that these proposed instructions were improper under the miniinal meaning of a discretionary sentencing power. Because they would require the prosecution to prove matters in aggravation by a preponderance of the evidence, while saying nothing of a similar burden on the defendant to prove matters in mitigation, their necessary implication is a preference for the lesser penalty. ${ }^{98}$ Apparently, however, it is equally proper to refuse instructions which would require the prosecution and the defense to sustain similar burdens of proof on particular facts they wish to prove, and which would hmit the jury's consideration to only those facts, whether in aggravation or mitigation of the penalty, which are proved by a preponderance of the evidence. In People v. Hines, ${ }^{00}$ the defendant requested an instruction that "aggravating and mitigating circumstances must be proved by a preponderance of the evidence." 100 The trial court rejected this instruction, and the supreme court affirmed on the authority of earlier cases holding that "such instructions erroneously himit the jury's absolute discretion in selection of a penalty." ${ }^{101}$ It is difficult to see, however, how such an instruction would himit the discretion of the jury. Regardless of the existence of non-evidentiary matters properly considered in selecting the penalty, the primary consideration should be the evidence presented at the penalty trial. Before the jury can properly assess the probative value of a particular fact as bearing on the punishment, the fact must be established. Under the broadened scope of evidence admissible at the penalty trial, much of the evidence introduced by each side will be uncontradicted. But when the existence or non-existence of a fact has been the subject of conflicting evidence, there should be a means for the jury to resolve the conflict prior to the consideration of that fact in aggravation or mitigation of the penalty. An instruction that facts inust be proved in order to be considered is simply a means of helping the jury to resolve conflicts in the evidence-an aid

95 People v. Purvis, 56 Cal.2d 93, 362 P.2d 713, 13 Cal. Rptr. 801 (1961); Pcople v. Ward, 50 Cal. 2d 702, 328 P.2d 777, cert. denied, 359 U.S. 945 (1958). See People v. Hines, ...... A.C. ....., 390 P.2d 398, 37 Cal. Rptr. 622 (1964); People v. Harrison, 59 Cal. 2d 618, 381 P.2d 64530 Cal. Rptr. 821 (1963); People v. Howk, 56 Cal. 2d 687, 365 P.2d 426, 16 Cal. Rptr. 370 (1961).

9647 Cal. 2d 209, 302 P.2d 307 (1957). See text accompanying notes 78-83 supra.

97 E.g., People v. Purvis, 56 Cal. 2d 93, 362 P.2d 713, 13 Cal. Rptr. 801 (1961).

98 Cf. id. at 102-03, 362 P.2d at 718-19, 13 Cal. Rptr. at 806-07 (dissenting opinion). 99 ..... A.C. ......, 390 P.2d 398, 37 Cal. Rptr. 622 (1964).

100390 P.2d at 404,37 Cal. Rptr. at 628.

101 Ibid. 
unhesitatingly provided, if not required, at the trial of other issues. When given in conjunction with an instruction that the jury has absolute discretion to select either penalty on the basis of the facts so proved, there would be no implication of a limitation on the jury's power to select either penalty. ${ }^{102}$

In addition, such an instruction would protect the defendant against certain speculative evidence similar to that disapproved of by the court in another context. For example, People v. Terry, ${ }^{103}$ decided the same day as People v. Hines, contains language that may impose a strict burden of proof on facts relating to other criminal conduct of the defendant. The Terry case held, inter alia, that an information could not be used to prove another offense allegedly committed by the defendant, because a jury has not so found "beyond a reasonable doubt." 104 In a footnote, the court went on to suggest that in the penalty trial the defendant should be accorded the same safeguards "as those which protect him in the trial in which guilt is established." ${ }^{105}$ Making express reference to the situation in which the prosecution introduces evidence of another alleged offense, the court said that the "defendant should not be subject to a finding of a jury that he committed prior crimes unless his commission of such prior crimes has been proven beyond a reasonable doubt." ${ }^{106}$ Hines and Terry together would seem to indicate this rule: under Hines the prosecution would carry no burden of proof whatsoever as to evidence of defendant's non-criminal misconduct (which may be just as damaging to the defendant in the eyes of the jury), while presumably Terry would require proof of the alleged criminal conduct to meet the stringent requirement of proof beyond a reasonable doubt. While there may be other plausible reasons for distinguishing the two situations, there is hittle reason for the distinction in terms of the effect on jury discretion. If any burden of proof on facts is deemed to interfere with jury discretion-itself a doubtful proposition-it would seem to be Terry's more restrictive "beyond a reasonable doubt" requirement. Whether the evidence relates to crimmal or non-criminal activities, a burden of proof on facts to be considered by the jury in the exercise of its discretion would seem to be a useful protective device.

The concept of absolute discretion in the jury has been held not to affect the statutory power ${ }^{107}$ of the trial court to reduce the pumishment in lieu of ordering a new trial. ${ }^{108}$ In passing on the defendant's motion for a new trial, the court has not only the power to reduce the punishment, but as iu other cases, the duty to judge the credibility of witnesses, determine the probative force of the testimony,

102 Since the jury will not, of course, consider facts unless they believe them to have been established, the failure of the trial court to give this instruction sliould not be reversible error. On the other hand, neither should the giving of such an instruction be reversible error on the ground that it interferes with the absolute discretion of the jury.

103 ...... A.C. ......, 390 P.2d 381, 37 Cal. Rptr. 605 (1964).

104390 P.2d at 389, 37 Cal. Rptr. at 613.

105 Ibid.

106 Ibid.

107 CaL. Pen. Code $\S 1181(7)$ : "When the verdict or finding is contrary to law or evidence, but in any case wherein authority is vested by statute in the trial court or jury to recommend or determine ... the punishment to be imposed, the court may modify such verdict or finding by imposing the lesser punishment without granting or ordering a new trial ...."

108 People v. Moore, 53 Cal. 2d 451, 348 P.2d 584, 2 Cal. Rptr. 6, cert. denied, 364 U.S. 895 (1960) (appeal taken by the People). See People v. Kroeger, ...... A.C. ......, 390 P.2d 369, 37 Cal. Rptr. 593 (1964). 
and weigh the evidence. ${ }^{109}$ Thus, whenever the jury is trier of fact on the issue of penalty, the imposition of the death penalty depends on the concurrent judgment of the trial court. ${ }^{110}$ This result is hardly required by section 190.1 , and is mconsistent with "absolute discretion" in the jury. In view of the extra-evidentiary factors deemed proper to the selection of punishment, an independent evaluation of the evidence adduced at the trial would seem to be an imsufficient basis to allow a trial court to reduce a verdict returned by the jury. Despite the inconsistency in theory, the vigorous use by the judge of the power to reduce the penalty is undoubtedly the most effective control of arbitrary action by the jury.111 Here is the clearest case of a departure from the theoretical concept of absolute discretion, a departure dictated by the practical need for control.

Judgments imposing the death penalty are by statute subject to automatic review by the California Supreme Court. ${ }^{112}$ This review extends both to the determination of guilt and to the determination of penalty. Since the guilt and penalty issues are completely separated, the court may reverse a judgment imposing the death penalty without affecting the judgment of guilt. That is, if no error occurred on the guilt phase of the trial, the conviction will be affirmed regardless of the disposition required of the judgment imposing the death penalty. The scope of review of the death sentence is then limited to determining whther prejudicial error ${ }^{113}$ occurred at the penalty trial. The court will not weigh the evidence on the punishment issue, even though it inight doubt the "appropriateness" of the

109 Ibid. Cf. People v. Borchers, 50 Cal. 2d 321, 325 P.2d 97 (1958); People v. Sheran, 49 Cal. 2d 101, 315 P.2d 5 (1957).

110 Thus the power of the jury, elsewhere described as "absolute," is qualified to an "exclusive power in the first instance ...." People v. Moore, 53 Cal.2d 451, 454, 348 P.2d 584, 586, 2 Cal. Rptr. 6, 8 (1960). (Emphasis added.) See Note, 13 Hastincs L.J. 474 (1962).

111 The trial judge is also allowed the right to comment on the evidence. People v. Friend, 50 Cal. 2d 570, 327 P.2d 97 (1958), noted, 6 U.C.L.A.L. REv. 149 (1959).

112 Cal. Pen. Code $\$ 1239$ (b). See generally Comment, 11 Stan. L. Rev. 94 (1958).

113 See CALIF. Const. art. 6, § 4I/2: "No judgment" shall be set aside, or new trial granted, in any case, on the ground of misdirection of the jury, or of the improper admission or rejection of evidence, or ... for any error as to any matter of procedure, unless, after an examination of the entire cause, including the evidence, the court shall be of the opinion that the error complained of has resulted in a miscarriage of justice." The settled interpretation of this scction is that "a 'miscarriage of justice' should be declared only when the court, 'after an cxamination of the entire cause including the evidence,' is of the 'opinion' that it is reasonably probable that a result more favorable to the appealing party would have been reached in the absence of the error." People v. Watson, 46 Cal. 2d 818, 836, 299 P.2d 243, 254 (1956). The court is divided on the proper application of this test to errors in the penalty trial. The majority argue that the unique character of the penalty determination, which the jury must make without benefit of standards or guidelines, renders it impossible to ascertain "whether an error which is not purely imsubstantial would cause a different result." People v. Hines, ...... A.C. ....., 390 P.2d 348, 37 Cal. Rptr. 622, 626 (1964). In Pcople v. Terry, ...... A.C. ......, 390 P.2d 381, 37 Cal. Rptr. 605, 616 (1964), Justice Tobriner stated: "To attempt to assess the effect of error in this legal vacuum is to superimpose one untestable surmise upon another." Therefore, the position of the majority is that "it necessarily follows that any substantial error occurring during the penalty phase of the trial, that results in the death penalty, since it reasonably may have swayed a juror, must be deemed to have been prejudicial." People v. Hamilton, 60 A.C. 51, 82-83, 383 P.2d 412, 431, 32 Cal. Rptr. 4, 23 (1963). See also People v. Linden, 52 Cal. 2d 1, 27, 338 P.2d 397, 402 (1959). Justice Schaucr, joined by Justice McComb, vigorously condemns the majority's treatment of penalty trial errors. He argues that whatever the difficulty of assessing the probability of a different result in the absence of error, the mandate of the constitutional provision is not fulfilled unless the court affirmatively concludes that "the error has resulted in a miscarriage of justice." People v. Hines, 390 P.2d 348, 37 Cal. Rptr. at 631 (dissenting opinion). 
death penalty in the particular case; if no prejudicial error occurred on the penalty phase of the trial, the judgment will be affirmed. ${ }^{114}$ If prejudicial error did occur in the penalty trial, the court has held that it may not reduce the death penalty to life imprisonment; it must reverse the judgment imposing the death penalty and remand to the trier of fact for a new trial solely on the issue of punishment.115

As an alternative to remanding for a new penalty trial, it might be desirable for the supreme court, upon a finding of prejudicial error $\mathrm{m}$ the penalty proceding, to reduce the punishment to life imprisonment. The basis for such a power in the court could be created by an amendment to the Penal Code similar to that recently enacted in New York. ${ }^{116}$ Actually, the power may already exist, althougl the California Supreme Court has consistently refused to exercise or even acknowledge it. Section 1181(7) of the Penal Code provides:

\begin{abstract}
When the verdict or finding is contrary to law or evidence, but in any case wherein authority is vested by statute in the trial court or jury to recommend or determine as a part of its verdict or finding the punishment to be imposed, the court may modify such verdict or finding by imposing the lesser punishment without granting or ordering a new trial, and this power shall extend to any court to which the case may be appealed.117
\end{abstract}

People v. Green, ${ }^{118}$ commonly cited as establishing the present rule requiring a remand upon a finding of prejudicial error relating to the selection of the penalty, did not mention this statute. ${ }^{119}$ In fact, the only penalty trial case construing the

114 E.g., People v. Rittger, 54 Cal.2d 720, 355 P.2d 645, 7 Cal. Rptr. 901 (1960); People v. Cash, 52 Cal. 2d 841, 345 P.2d 462 (1959); People v. Brust, 47 Cal. 2d 776, 306 P.2d 480 (1957) ; People v. Odle, 37 Cal. 2d 52, 230 P.2d 345 (1951).

115 E.g., People v. Cash, supra note 114; People v. Linden, 52 Cal. 2d 1, 338 P.2d 397 (1959). See People v. Green, 47 Cal. 2d 209, 235, 302 P.2d 307, 325 (1956).

110 "On an appeal by the defeandant where the judgment is of death, the court ... if it finds substantial error only in the sentencing proceeding, may set aside the sentence of death and remand the case to the trial court, in which event the trial court shall impose the sentence of life imprisonment." N.Y. PENaL LAw § 1045-a.

117 (Emphasis added.)

11847 Cal.2d 209, 302 P.2d 307 (1956). Note that at the time of this decision the separate trial procedure for determining punishment had not yet been enacted.

119 The opinion disposed of the issue with this language: "In some situations of error related solely to the question of punishment, that error could be corrected by the . . . court's reducing the punishment, but that cannot be done here because under the pertinent statutes as construed by this court the trier of fact is vested with exclusive discretion to determine punishment (see People v. Odle . . . People v. Thomas . . . .)" 47 Cal. $2 d$ at 235, 302 P.2d at 324-25 (1956). Both cases cited had left that question undecided. People v. Odle, $37 \mathrm{Cal}$. $2 ₫$ 52, 230 P.2đ 345 (1951), and People v. Thomas, 37 Cal. 2d 74, 230 P.2đ 351 (1951), were concerned with the power of the supreme court under Penal Code Section 1260 to reduce a death sentence to life in the absence of error in the proceedings. It provides: "The court may reverse, affirm, or modify a judgment or order appealed from, or reduce the degree of the offense or the punishment imposed . . ." CAI. PEN. CODE $\$ 1260$ (Emphasis added). The italicized portion of the statute had been added in 1949, Cal. Stat. ch. 1309, $\$ 1$, p. 2297, and was construed by Justice Traynor, writing for the court in People v. Odle: "Section 1260 now makes clear that the court can reduce the punishment in lieu of ordering a new trial, when the only error relates to the pumshinent imposed. It does not, however, vest power in the court to modify a judgment in the absence of error in the proceedings." 37 Cal. 2d at 57, 230 P.2d at 348. In a separate concurring opinion in Odle, Justice Shenk stated: "I do not agree with the definite implication in the majority opinion that this court has the power to reduce the punishment ... even in the presence of error." Although Shenk's view prevailed in Green, it has never been clearly explained why the supreme court could not, under $\$ 1260$, reduce a death sentence to life imprisonment upon a finding of prejudicial error relating to the punishment. For an example of a case in which the power of the court 
statute, People v. Moore, ${ }^{120}$ upheld the power of the trial court to reduce a death sentence to life imprisonment in lieu of granting a new penalty trial. ${ }^{121}$ The statutory power of the trial court was held unimpaired despite the concept of an absolute discretion in the jury to select either penalty. ${ }^{122}$ In light of the clear language of section $1181(7)$ conferring similar powers on reviewing courts, there seems to be no reason why the supreme court could not reduce a death sentence to life imprisonment as an alternative to remanding for a new penalty trial.

Whatever the interpretation to be given to section 1181(7), compelling reasons exist for making some change in the present practice of remanding for completely new penalty trials after a finding of prejudicial error. Remanding is expensive and time-consuming. ${ }^{123}$ In an ever increasing number of cases in which the defendant has been fairly tried and convicted of a capital offense, the conviction being affirmed by the supreme court, the final determination of pumishment has been in question for years. ${ }^{124}$ Once a conviction has been secured and sustained on appeal, it is highly doubtful that any interest of the state is served by successive trials for the purpose of securing froin a jury the choice as to life or death. Surely any interest that may be served is outweighed by the questionable practice of submitting a defendant to successive trials for his life.

\section{CONCLUSION}

An ultimate evaluation of the separate trial procedure for determining punishment iuevitably will be tainted by attitudes toward the death penalty. Assuming, however, the retention of the death penalty as an alternative in certain classes of offenses, the separation of the determination of punishment from the determination of guilt is a first step in implementing the goal of imposing a socially useful punishment in each case. The separate trial procedure advances two goals. The first is avoiding prejudice to the defendant on the issue of guilt, since evidence relevant solely to punishment will not be allowed until guilt has been established. Secondly, an extensive inquiry into the defendant's background and character and the circumstances of his crime provides a basis for an informed selection of penalty. Standing alone, these results would seein to recommend the separate trial procedure to legislators and judges concerned with effective administration of the death penalty.

to reduce the punishment without remanding for a new trial is settled, see People v. Jackson, $44 \mathrm{Cal} .2 \mathrm{~d} 511,282$ P.2d 898 (1955) (in the absence of evidence that kidnapping victim suffered bodily harm no authorization for the death penalty under Penal Code Section 209). 12053 Cal. 2d 451, 348 P.2d 584, 2 Cal. Rptr. 6 (1960).

121 See note 113 stipra.

122 For a criticism of this holding see Note, 13 Hasings L.J. 474 (1962).

123 One major disadvantage of a new trial solely on the issue of punishment is that the new jury empaneled for this purpose has not heard the evidence relating to the crime for which the penalty is being determined. Thus, while only penalty is technically in issue (guilt having been conclusively established by the affirmance of the conviction on appeal), the prosecution must repeat most of the evidence introduced at the guilt phase of the prior trial. The necessity of repeating this evidence adds appreciably to the length of time required to retry the penalty issue.

124 People v. Purvis, 52 Cal. 2d 871, 346 P.2d 22 (1959) (prosecution misconduct, resentenced to death), rev'd, 56 Cal. 2d 93, 362 P.2d 713, 13 Cal. Rptr. 801 (1961) (prosecution misconduct, resentenced to death), rev'd 60 A.C. 277, 384 P.2d 424, 33 Cal. Rptr. 104 (1963) (prosecution misconduct). Purvis' fourth penalty trial, which was to begin on Monday, April 13, 1964 has been stayed by Justice Douglas in order to permit him to appeal to the United States Supreme Court. San Francisco Chromicle, April 11, 1964, p. 4 col. 2. 
On the other hand, the separate trial procedure, with the jury as the organ of discretion, accentuates the theoretical and practical difficulties of establishing an enlightened sentencing scheme. When the legislature does not purport to resolve certain fundamental questions-such as the proper basis (if any) for differentiating between offenders potentially subject to the death penalty-that task falls to the courts. The active role of the California Supreme Court has been directed at what the penalty proceeding slould not encompass. The court has ruled that appraisal of the relative turpitude of an individual defendant should not be influenced by such matters as the unproven (and perhaps unprovable) proposition that the death penalty is a superior deterrent to crime, or by speculation as to wliat an expert body might do if in the future it must decide whether or not to parole the defendant. While such himitations seem necessary, what remains as the grounds for decision is uncertain. Perliaps it may be no inore than a visceral reaction of the jury to the defendant. This may be the only solution, and possibly the one contemplated by the legislature. Unfortunately, it does not lend itself to the formation of concrete rules or standards by which an adversary penalty proceding may be conducted.

Franklin P. Glenn 